\title{
UPORABNOST SPLETNE STRANI TEACHER'S CLIMATE GUIDE ZA SAMOIZOBRAŽEVANJE ANDRAGOGOV IN NAČRTOVANJE IZOBRAŽEVANJA ODRASLIH O OKOLJSKI PROBLEMATIKI
}

Okoljsko problematiko danes srečujemo pri vseh vidikih družbenega življenja. Gre za eksistencialni problem človeštva, ki zadeva tudi področje izobraževanja odraslih. Spletha stran Teacher's Climate Guide (https://teachers-climate-guide.fi/), ki jo ureja finska okoljska izobraževalka Pinja Sipari, ponuja kakovostno izhodišče za spoznavanje okoljskega izobraževanja in poglabljanje vanj. Stran zajema 21 tematik (npr. kemija, biologija, geografija, družbene vede (social studies), fizika, umetnost, zgodovina), ki jih spremljajo tudi predlogi za izvajanje raznih nalog, ki lahko služijo kot pomoč pri zastavljanju vzgojno-izobraževalnega procesa. Takšna spletna platforma je lahko pomemben vir za razvoj različnih oblik izobraževanja odraslih, ki se osredotočajo na okoljske spremembe in preoblikovanje posameznikovih vrednot. Predstavljamo nekaj vsebinskih poudarkov iz izobraževanja o okoljski problematiki s spletne platforme, ki je lahko v pomoč pri pripravi interdisciplinarno in holistično zasnovanega izobraževanja odraslih.

Tematski sklop kemije nam odpira vrata $\mathrm{v}$ razumevanje sestave atmosfere, nastajanja toplogrednih plinov in segrevanja ozračja, nastanka učinka tople grede, ogljičnega cikla ipd. Poleg ozračja so glavno odlagališče emisij ogljikovega dioksida oceani. Vse večje kopičenje emisij na morskem dnu negativno vpliva na tam živeče organizme. V povezavi z biologijo lahko tako dobimo globlje razumevanje vplivov človeka na okolje in žive organizme. »Človek s svojimi posegi v prostor in drugimi aktivnostmi povečuje dovzetnost vrst za izumiranje. Sprememba rabe zemljišč, kmetijstvo in urbanizacija, gradnja infrastrukture avtocest, čezmerno izkoriščanje, onesnaževanje, turizem, podnebne spremembe ter nove vrste, ki konkurirajo naravni flori in favni, so povzročili množično izumiranje, « je zapisala Kajfež Bogataj (2017, str. 137). Skozi zgodovinski pogled je možno ozaveščanje o odgovornosti, ki jo ima kapitalistični zahod za reševanje problematike, in tudi zavedanje izkoriščanja, ki ga kapitalistični zahod izvaja na globalnem vzhodu. Prav tako nam zgodovina ponuja vpogled v sistemska spreminjanja družb. Zgodovina nam tako omogoča razumevanje poteka razvoja tehnologij, pojava masovnih okoljskih sprememb z začetkom med industrijsko revolucijo itd.; geografija pa uvid v vpliv teh sprememb na globalni in lokalni ravni. Sociologija proučuje vplive na ljudi kot skupnost in tudi vplive, ki se dotikajo neposredno posameznikov (vprašanje gentrifikacije in s tem povezana stanovanjska problematika, vprašanje prekarizacije idr.). Migracije so tipičen tematski sklop, ki povezuje različna področja: geografijo, ekonomijo, sociologijo, biologijo ipd. Zaradi 
segrevanja ozračja se bo zmanjševala biodiverziteta, kar bo posredno privedlo do lakote oziroma do okolja, kjer poljedelstvo in posledično živinoreja ne bosta več mogoča. Zaradi pomanjkanja dobrin se bodo pojavile okoljske migracije, nastale bodo vojne, ki bodo migracije še pospešile. Sprva se bodo te spremembe dogajale $v$ revnejših predelih sveta - favelah v Braziliji, podsaharski Afriki ipd. -, v nadaljevanju pa tudi v državah, kamor se bodo podnebni begunci zatekli. Področje matematike in fizike je tisto, ki prek statističnih napovedi prispeva $\mathrm{k}$ razumevanju poteka okoljskih sprememb, kakor denimo tudi $\mathrm{k}$ razumevanju valovne optike, ki pojasnjuje odbijanje svetlobe od različnih površin (taljenje ledu predvsem na severni Zemljini polobli pripomore k večjemu segrevanju ozračja; led zaradi svoje bele barve odbija več svetlobe kot temna barva oceana, kar ustvarja pozitivno povratno zanko).

Psihologija lahko pripomore k reševanju različnih stisk, prav tako lahko oblikuje različne strategije za spopadanje s tesnobami, ki so rezultat okoljske problematike. Tudi umetnost lahko vpliva na posameznikovo procesiranje čustev (glasbena terapija), skozi estetsko občutenje umirja, skozi aktivizem povezuje idr. Okoljske spremembe vplivajo tudi na posameznika in njegove vrednote, na kar se osredotoča etika, ki obravnava vprašanje podnebne pravičnosti (odgovornost zahodnih kapitalističnih držav za globalno segrevanje, neokolonializem) in kršenje temeljnih človekovih pravic (ogrožene so pravica do življenja, hrane, vode, zdravja, izobraževanja, kulture idr.).

Pomembna sta tudi jezikovna in medijska pismenost. Medijsko pismena oseba je vešča $\mathrm{v}$ analiziranju in odkrivanju stereotipov, vrednot, ideologij ter je sposobna interpretirati številne pomene in sporočila, ki so zajeti v besedilih. Zato je pri posameznikih treba spodbujati kritično mišljenje.

S tem kratkim prikazom smo želeli pokazati, da je spletna stran Teacher's Climate Guide kakovosten vir za samostojno učenje, pri razvoju programov pa jo lahko uporabijo tudi izobraževalci odraslih. Spletna stran andragogom pomaga do osnovnega razumevanja okoljske problematike ter jih napotuje na nadaljnje raziskovanje in poglabljanje v posamezne tematske sklope.

Andraž Fink

\section{LITERATURA}

Kajfež Bogataj, L. (2017). Planet, ki ne raste. Cankarjeva založba. 